\title{
Cobweb as novel biomaterial for the green and eco-friendly synthesis of silver nanoparticles
}

\author{
A. Lateef ${ }^{1}$ - S. A. Ojo ${ }^{1} \cdot$ M. A. Azeez ${ }^{1}$ T. B. Asafa ${ }^{2}$ T. A. Yekeen ${ }^{1}$. \\ A. Akinboro $^{1}$ - I. C. Oladipo ${ }^{3}$ E. B. Gueguim-Kana ${ }^{4}$ L. S. Beukes ${ }^{5}$
}

Received: 16 June 2015/Accepted: 10 August 2015/Published online: 27 August 2015

(c) The Author(s) 2015. This article is published with open access at Springerlink.com

\begin{abstract}
In this study, spider cobweb as a novel biomaterial was used for the green synthesis of silver nanoparticles (AgNPs). The synthesized AgNPs were characterized using UV-Vis spectroscopy, Fourier-transform infrared spectroscopy (FTIR), and transmission electron microscopy. The efficacy of biosynthesized particles as antibacterial agents was evaluated using multidrug resistant clinical bacterial isolates through sensitivity testing with AgNPs and combination of AgNPs with some selected antibiotics. In addition, the potential application of the particles as additives in paints was demonstrated using some bacterial and fungal isolates. The synthesized AgNPs which were dark brown in color displayed maximum absorbance at the wavelength of $436 \mathrm{~nm}$. It was observed that the reaction mixture of 1:40 (extract: $\mathrm{AgNO}_{3}$ solution)
\end{abstract}

A. Lateef, M. A. Azeez, T. B. Asafa, T. A. Yekeen, A. Akinboro and I. C. Oladipo are members of the Nanotechnology Research Group $\left(\mathrm{NANO}^{+}\right)$.

\section{A. Lateef}

agbaje72@yahoo.com; alateef@lautech.edu.ng

1 Department of Pure and Applied Biology, Ladoke Akintola University of Technology, PMB 4000, Ogbomoso, Nigeria

2 Department of Mechanical Engineering, Ladoke Akintola University of Technology, PMB 4000, Ogbomoso, Nigeria

3 Department of Science Laboratory Technology, Ladoke Akintola University of Technology, PMB 4000, Ogbomoso, Nigeria

4 Department of Microbiology, School of Life Sciences, University of KwaZulu-Natal, Private Bag X01, Scottsville, Pietermaritzburg 3209, South Africa

5 Microscopy and Microanalysis Unit, School of Life Sciences, University of KwaZulu-Natal, Private Bag X01, Scottsville, Pietermaritzburg 3209, South Africa at $\mathrm{pH}$ of 8.5 produced particles with maximum absorbance at $436 \mathrm{~nm}$. The FTIR spectrum showed peaks at 3298, 2359, 2089, and $1635 \mathrm{~cm}^{-1}$, indicating that proteins were the capping and stabilization molecules in the synthesis of AgNPs. The particles were spherical in shape with size ranging about $3-50 \mathrm{~nm}$. The energy-dispersive X-ray analysis showed the presence of silver as the most prominent metal, while the selected area electron diffraction pattern conformed to the face-centered cubic phase and crystalline nature of AgNPs. The AgNPs inhibited the growth of several bacterial isolates including $S$. aureus, E. coli, Klebsiella granulomatis and P. aeruginosa in the range of $10-17 \mathrm{~mm}$ at concentration of $100 \mu \mathrm{g} / \mathrm{ml}$. It was also demonstrated that AgNPs potentiated the activities of augmentin, ofloxacin and cefixime in the AgNP-antibiotic synergy studies. Similarly, the inclusion of AgNPs as additive in white emulsion paint led to the total inhibition of growth of E. coli, P. aeruginosa, Aspergillus niger and A. fumigatus. To the best of our knowledge, this is the first report of the use of cobweb for the green synthesis of AgNPs. The immense antimicrobial activities of the particles can be explored in the creation of novel products, where it can be used as additive to protect materials against microbial attack.

Keywords Cobwebs - Biomaterial - Silver nanoparticles · Antimicrobial · Multi-drug resistance $\cdot$ Synergy $\cdot$ Paints

\section{Introduction}

The green synthesis of nanoparticles has continued to receive unprecedented attention due to the simplicity of the process, less handling of chemicals and eco-friendliness (Salem et al. 2014). In addition, the availability of several 
biological macromolecules/substances that can serve as capping and stabilization molecules for the green synthesis of nanoparticles has also contributed to the steady rise of this process. Several authors have used bacteria, fungi, algae and plant extracts for the green synthesis of metal nanoparticles (Shivaji et al. 2011; Salem et al. 2014; Augustine et al. 2014; Shanmugam et al. 2014; Nazeruddin et al. 2014; Rajeshkumar et al. 2014; Raliya and Tarafdar 2014; Mishra et al. 2014; Lateef et al. 2015a, b; El-Batal et al. 2015). However, there is lack of information on the use of metabolites of arthropods for the green synthesis of nanoparticles.

Arthropods form the phylum Arthropoda, which consists of the insects, arachnids, myriapods and crustaceans. Arthropods are characterized by their jointed limbs and cuticle made of $\alpha$-chitin and/or calcium carbonate (Cutler 1980). It has been estimated that the number of arthropod species varies between $1,170,000$ and 5-10 million accounting for over $80 \%$ of all known living animal species (Ødegaard 2000). The four major groups of arthropods are: Chelicerata (spiders and scorpions), Crustacea (shrimps, lobsters, crabs), Tracheata (insects and myriapods), and the extinct trilobites (Ruppert et al. 2004). There are approximately 40,000 species of spiders in the World (Insect Identification 2015) out of nearly 1.7 million described species of plants, animals, fungi, bacteria, and protists (DMNS 2015). Spiders are 8-legged creatures that have chitinous coverings and two body regions, the cephalothorax (head and thorax as one external unit) and the abdomen (Glime 2013). Unlike the insects, they lack antennae. Instead, they have various hairs that penetrate their chitinous covering.

Spiders have been described as the pre-eminent silk craftsmen among arthropods, which are best known for producing aerial orb webs that are used for capturing flying insects (Blackledge et al. 2011). The silk threads that are woven into arrays of structures are constructed by spiders for wide range of purposes such as simple lifelines, shelters, for moulting, protection of egg sacs and webs. The fibers produced by orb web spiders have been ranked among the strongest, stretchiest, and toughest biomaterials known to man. They are instantaneously assembled from liquid protein feedstock inside the spiders' bodies (Blackledge et al. 2011). Spider cobweb had been previously reported to be rich in amino acids including glycine and alanine and large amounts of pyrrolidine (Roozbahani et al. 2014). Spiders' silk has been a biomaterial used by man for different applications, such as wound healing because of the presence of vitamin K (Heimer 1988) and antimicrobial activities (Chakraborty 2009; Gomes et al. 2010; Roozbahani et al. 2014). Therefore, the present work seeks to extend the frontiers of biotechnological applications of spiders, particularly the utilization of their cobwebs.
Therefore, this study was conceived to evaluate the use of cobweb of spider for the synthesis of silver nanoparticles, and evaluate the synthesized AgNPs for their antimicrobial activities against multi-drug resistant clinical bacterial isolates, and as antimicrobial additive in paints. Until now, there is no report on the use of spider cobweb for the green synthesis of nanoparticles.

\section{Materials and methods}

\section{Spider cobwebs}

Spider cobwebs used in this study were obtained from a residential building using a stick to collect the webs. The webs were taken to the laboratory and washed thoroughly using distilled water to remove dust and other extraneous materials. The washed web was allowed to air-dry at room temperature $\left(30 \pm 2{ }^{\circ} \mathrm{C}\right)$ and kept in air-tight container until further use.

\section{Green synthesis and characterization of AgNPs}

The green synthesis of AgNPs was carried using hydrolyzed cobwebs. The modified method of Tszydel et al. (2009) was used to hydrolyze the cobwebs. About $0.1 \mathrm{~g}$ of cobwebs was weighed and hydrolyzed with $10 \mathrm{ml}$ of $0.1 \mathrm{M}$ $\mathrm{NaOH}$ at $90{ }^{\circ} \mathrm{C}$ for $1 \mathrm{~h}$. The hydrolyzed cobweb was allowed to cool and then centrifuged at $4000 \mathrm{rpm}$ for $30 \mathrm{~min}$. The supernatant obtained designated as cobweb extract was used to synthesize AgNPs as previously described (Lateef et al. 2015a). About $1 \mathrm{ml}$ of cobweb extract was added to the reaction vessel containing $40 \mathrm{ml}$ of $1 \mathrm{mM}$ silver nitrate $\left(\mathrm{AgNO}_{3}\right)$ solution for the reduction of silver ion. The reaction was carried out in static condition at room temperature $\left(30 \pm 2{ }^{\circ} \mathrm{C}\right)$ for $2 \mathrm{~h}$. The formation of AgNPs was monitored through visual observation of the change of color and measurement of the absorbance spectrum of the reaction mixture using UVvisible spectrophotometer (Cecil, USA). The effects of $\mathrm{pH}$, and increasing volume of $\mathrm{AgNO}_{3}$ solution on the formation of AgNPs were monitored by measuring the absorbance at wavelength where maximum absorbance occurred.

Fourier-transform infrared (FTIR) spectroscopy analysis was carried out using IRAffinity-1S Spectrometer (Shimadzu, UK) on the powder sample of AgNPs according to Bhat et al. (2011). The AgNP solution was centrifuged at 10,000 rpm for $20 \mathrm{~min}$. The solid residue obtained was then dried at room temperature, and the powder obtained was used for FTIR measurement using $\mathrm{KBr}$ pellets.

The transmission electron microscopy (TEM) micrograph was obtained as follows. A drop of nanoparticles in suspension was placed on a 200 mesh hexagonal copper grid 


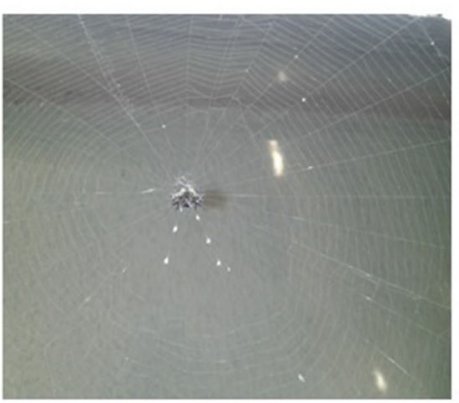

Spider cobweb

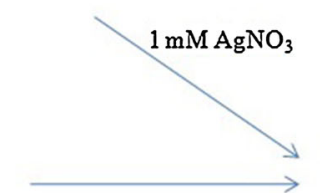

Hydrolysis with $0.1 \mathrm{M} \mathrm{NaOH}$ at $90^{\circ} \mathrm{C}$ for $1 \mathrm{~h}$

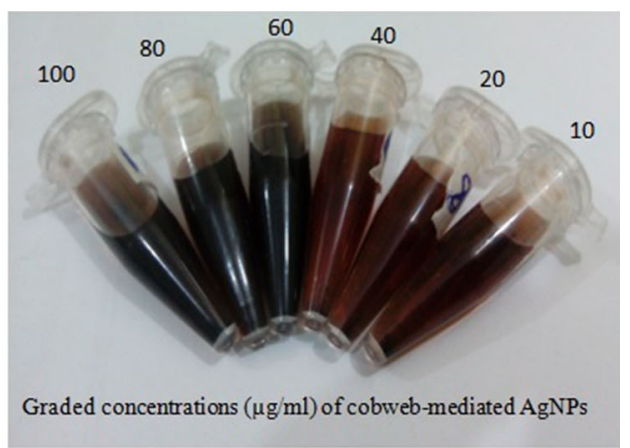

Fig. 1 Green synthesis of AgNPs using cobweb

Fig. 2 The UV-Vis absorption spectrum of the freshly prepared (a) and stored

(b) biosynthesized AgNPs

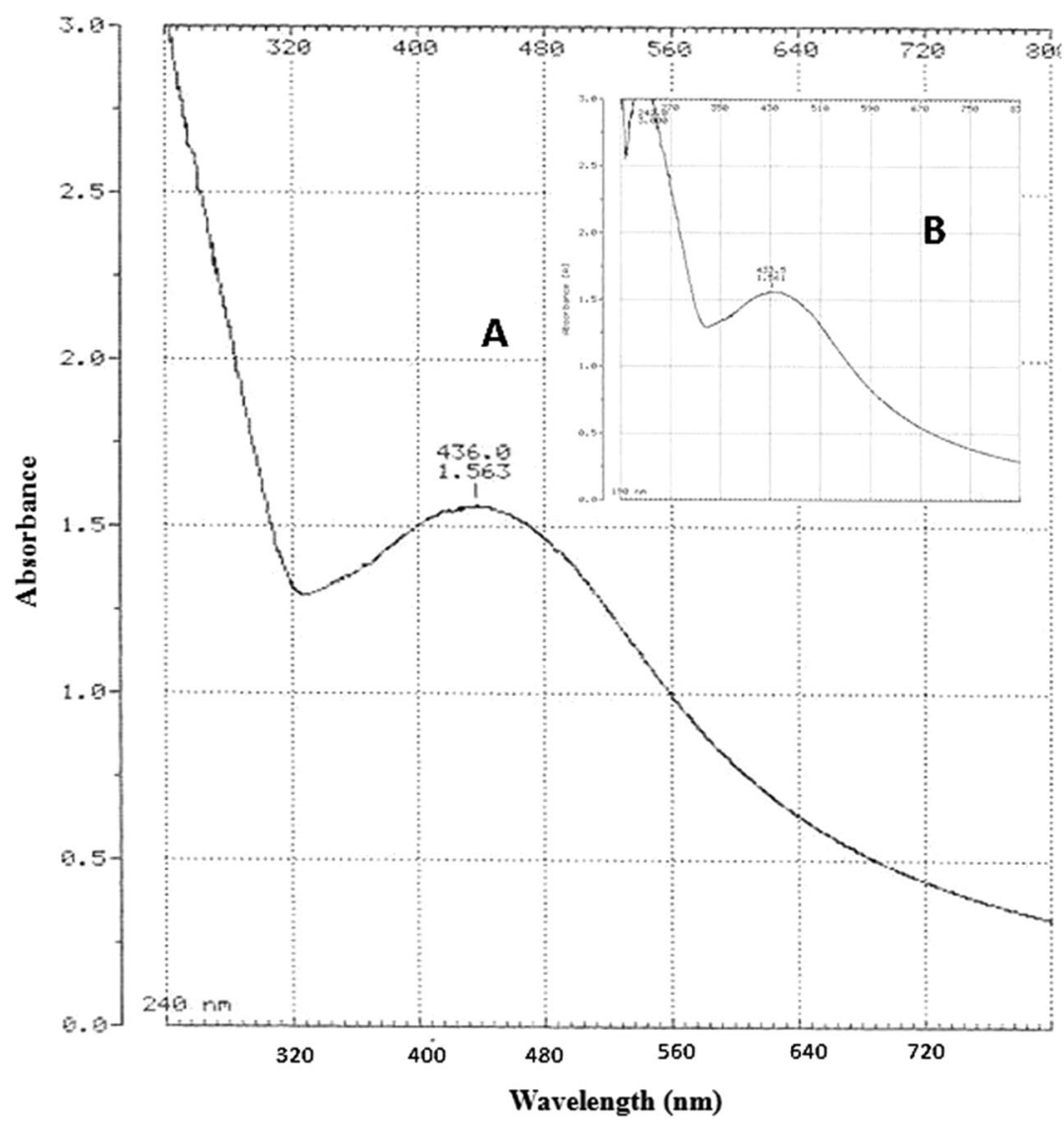

(3.05 mm) (Agar Scientific, Essex, UK) coated with $0.3 \%$ formvar dissolved in chloroform. The particles were allowed to settle for 3-5 min on the grid, the excess liquid flicked off with a wick of filter paper and the grids were then air dried before TEM viewing. Micrograph was obtained using a JEM-1400 (JEOL, USA) operating at $200 \mathrm{kV}$.

\section{Antimicrobial activities of synthesized AgNPs}

The antibacterial property of the synthesized AgNPs was investigated using the agar-diffusion method. Clinical isolates of Escherichia coli, Klebsiella granulomatis,
Pseudomonas aeruginosa, and Staphylococcus aureus obtained from LAUTECH Teaching Hospital, Ogbomoso, were used as test organisms. Each bacterium was grown overnight in peptone water, and 18-h culture was used to seed the plates of Mueller-Hinton Agar (Lab M Ltd.) with the aid of sterile cotton swab stick. The plates were then bored using cork borer $(7 \mathrm{~mm})$ to create wells. The wells were irrigated with $100 \mu \mathrm{l}$ of graded concentrations of AgNPs prepared by dispersion in sterile distilled water. The plates were thereafter incubated at $37{ }^{\circ} \mathrm{C}$ for $24 \mathrm{~h}$. At the end of incubation, plates were examined for the zones of inhibition, which were measured. 


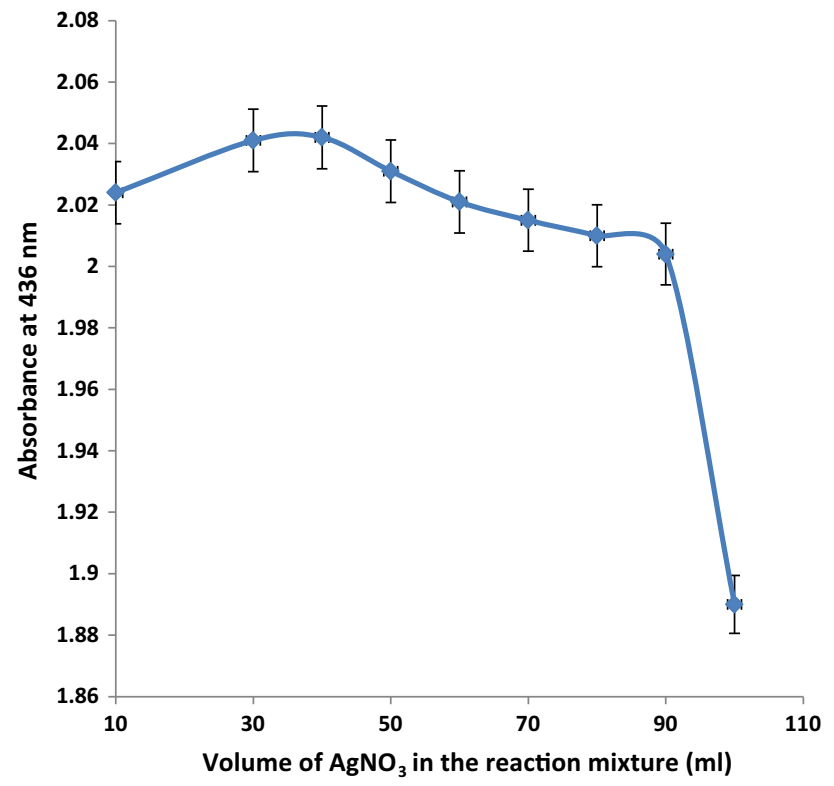

Fig. 3 The effect of increasing volume of $\mathrm{AgNO}_{3}$ solution on the absorbance of biosynthesized AgNPs at the wavelength of $436 \mathrm{~nm}$

\section{Antimicrobial susceptibility test}

The test bacterial isolates were screened for susceptibility using a panel of antibiotics on Mueller-Hinton Agar plates by disc diffusion as previously demonstrated (Lateef et al. 2010; Lateef and Ojo 2015). The bacterial isolates were tested on the discs (Abtek Biologicals Ltd., $\mathrm{UK})$ impregnated with antibiotics containing $(\mu \mathrm{g})$ : ceftazidime (Caz), 30; cefuroxime (Crx), 30; gentamicin (Gen), 10; cefixime (Cxm), 5; ofloxacin (Ofl), 5; augmentin (Aug), 30; nitrofurantoin (Nit), 300; and ciprofloxacin (Cpr), 5 for Gram-negative isolates. ceftazidime (Caz), 30; cefuroxime (Crx), 30; gentamicin (Gen), 10; ceftriaxone (Ctr), 30; erythromycin (Ery), 5; cloxacillin (Cxc), 5; ofloxacin (Ofl), 5; and augmentin (Aug), 30 were used for the Gram-positive isolates. The plates were incubated at $37{ }^{\circ} \mathrm{C}$ for $48 \mathrm{~h}$, and afterwards, the zones of inhibition were examined and interpreted accordingly (Chortyk et al. 1993) considering the appropriate breakpoints (Andrews 2005).

\section{Synergistic studies on antibiotic-AgNP mixtures}

Studies were conducted on the compatibility and synergistic attributes of the synthesized AgNPs with some commercial antibiotics such as augmentin, ofloxacin and cefixime. The agar-diffusion method as previously described was used. Graded concentrations $(500 \mu \mathrm{g} / \mathrm{ml}$ and $1 \mathrm{mg} / \mathrm{ml}$ ) of the antibiotics were prepared using sterile distilled water, and $100 \mu \mathrm{l}$ of each was introduced into the

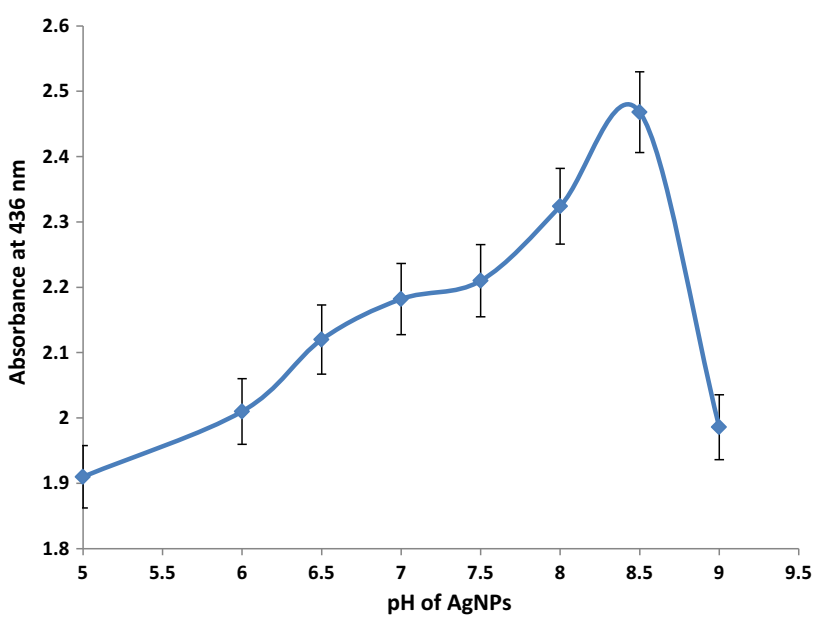

Fig. 4 The effect of $\mathrm{pH}$ on the absorbance of the biosynthesized AgNPs at the wavelength of $436 \mathrm{~nm}$

agar wells. For the compatibility/synergistic studies, equal volumes $(50 \mu \mathrm{l})$ of the antibiotic and AgNPs $(100 \mu \mathrm{g} / \mathrm{ml})$ were mixed together and used against the test organisms. After incubation as previously described, the zones of inhibitions were determined and compared to calculate the percentage improvement in antibacterial activities as a result of synergy between antibiotics and synthesized AgNPs.

\section{Evaluation of antimicrobial properties of synthesized AgNPs as additive in paint}

The potential protective attributes of the synthesized AgNPs were studied by incorporating AgNPs in emulsion paint. Commercially available white emulsion paint was procured and prepared according to manufacturer's instructions. The paint was dispensed as $19 \mathrm{ml}$ in McCartney bottles and autoclaved at $121{ }^{\circ} \mathrm{C}$ for $15 \mathrm{~min}$. Thereafter, the paints were inoculated with $1 \mathrm{ml}$ of $18-\mathrm{h}$ broth cultures of E. coli, and P. aeruginosa. For Aspergillus flavus, Aspergillus fumigatus and Aspergillus niger, $1 \mathrm{ml}$ of $48 \mathrm{~h}$ culture was used as inoculum. While the control experiment consisted of the paints and test organisms only, the test experiment consisted of the paint, test organism and $1 \mathrm{ml}$ of $100 \mu \mathrm{g} / \mathrm{ml}$ of biosynthesized AgNPs to produce a final AgNP concentration of $5 \mu \mathrm{g} / \mathrm{ml}$. The bottles were incubated at 37 and $30 \pm 2{ }^{\circ} \mathrm{C}$ for $48 \mathrm{~h}$ for bacteria and fungi, respectively. At the end of incubation, $1 \mathrm{ml}$ of the contents of each bottle was used to inoculate fresh plates of nutrient agar for bacteria, and potato dextrose agar for fungi using the pour plate method. The plates were then incubated at appropriate temperatures for up to $48 \mathrm{~h}$. The plates were observed for growth at the end of incubation. 
Fig. 5 The FTIR spectrum of the biosynthesized AgNPs

ФSHIMADZU

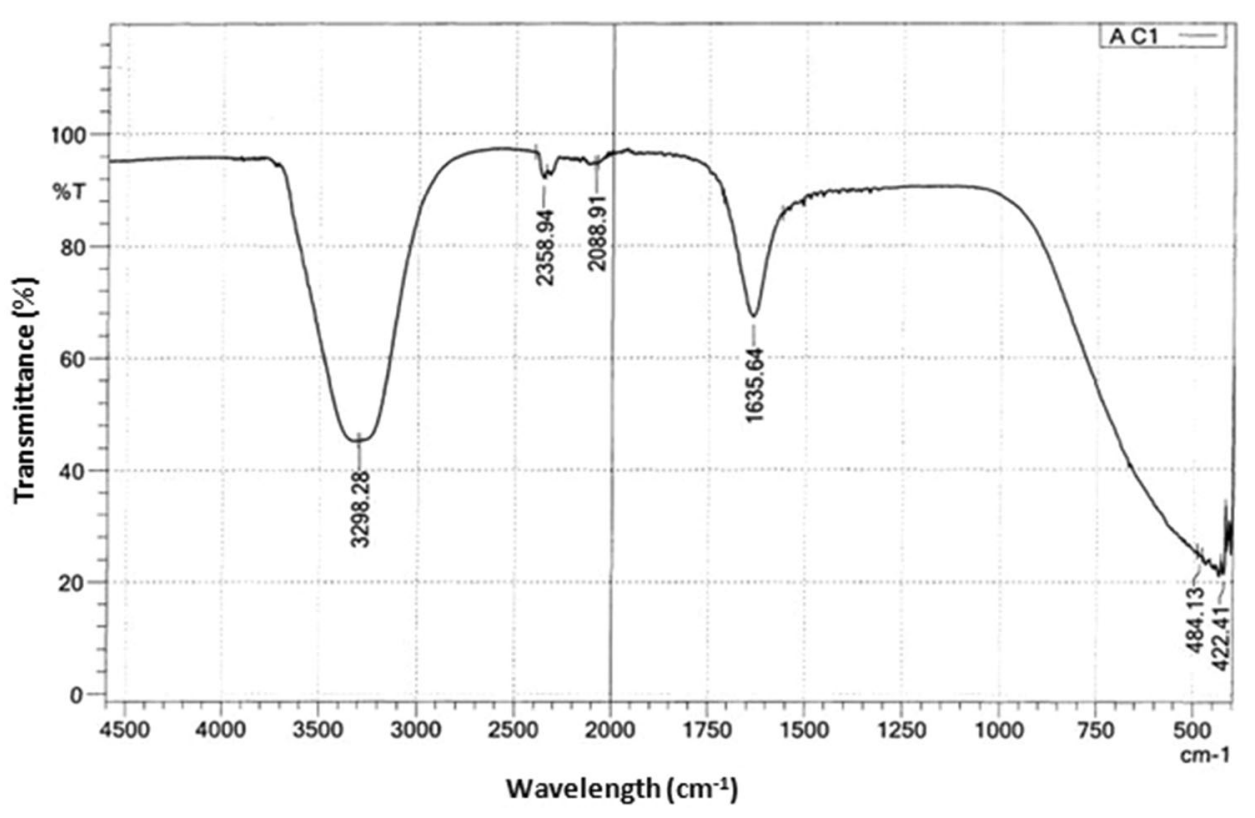

Fig. 6 Transmission electron micrograph (a), selected area electron diffraction pattern (b) and energy-dispersive X-ray signal (c) of the biosynthesized AgNPs

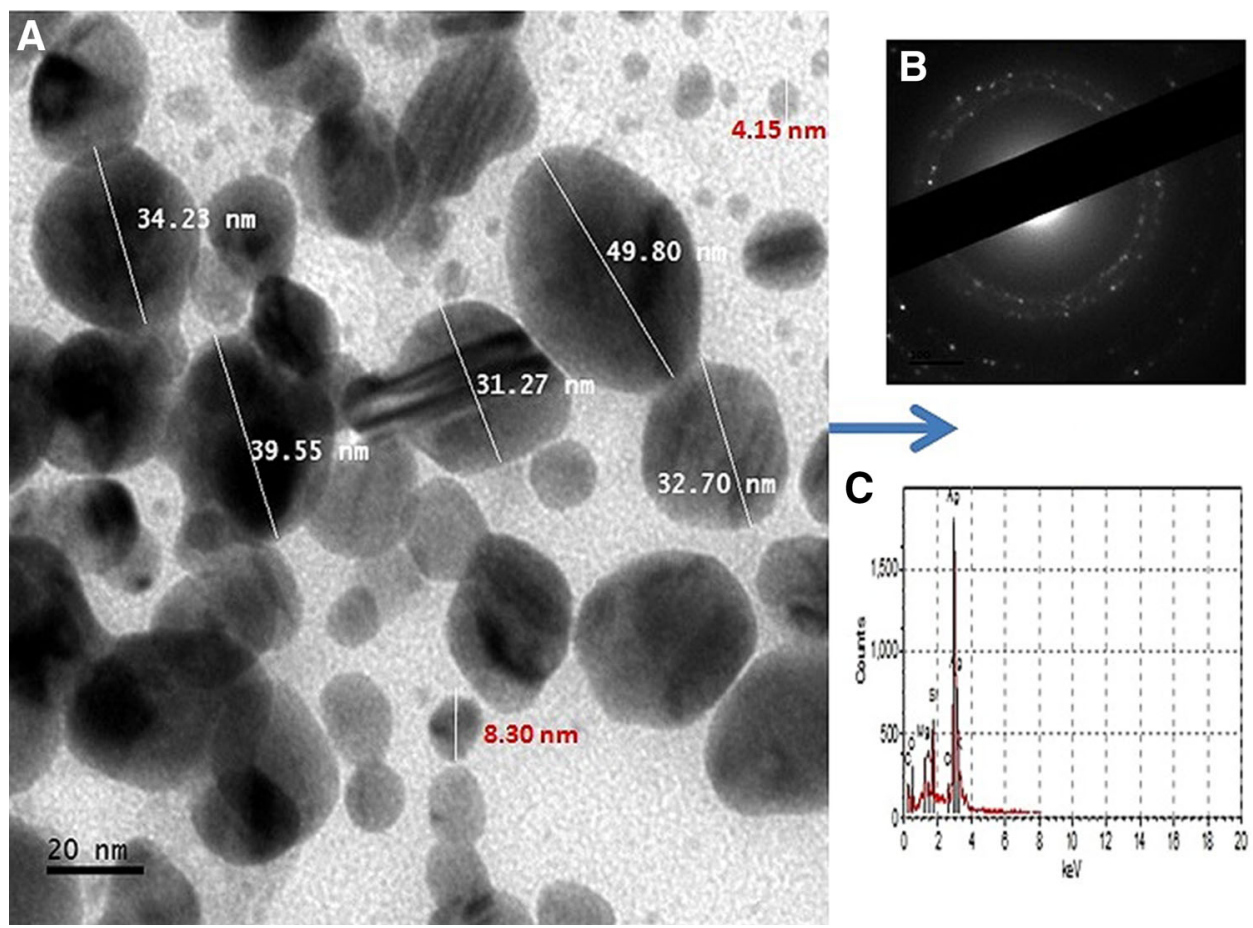

\section{Results and discussion}

\section{Spider cobweb}

The cobweb used in this study was obtained from the nest of domestic house spider, Tegenaria domestica (Fig. 1), which showed orb web architecture (Blackledge et al. 2011). Spider cobwebs have also been used for the monitoring of pollution in industrial and residential areas (Hose et al. 2002; Ayedun et al. 2013), while spiders have been used as bio-control agents in reducing populations of insect pests on farmlands (Maloney et al. 2003). In addition, venoms of spiders have been evaluated for the treatment of cardiac arrhythmia (Novak 2001), Alzheimer's disease (Lewis and Garcia 2003) and erectile dysfunction (Andrade et al. 2008). 
Fig. 7 The antibacterial activities of synthesized AgNPs against some clinical bacterial isolates
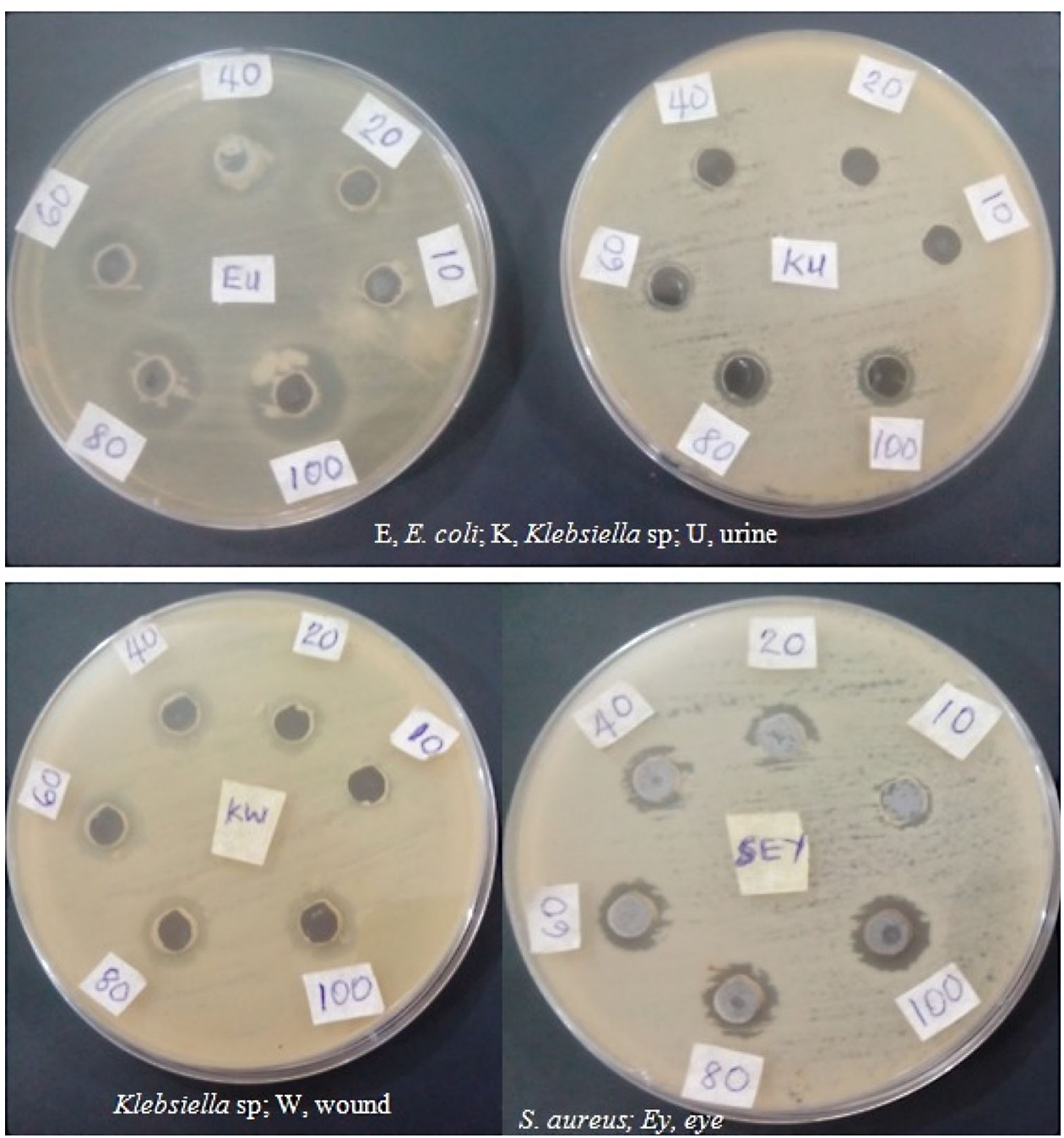

Table 1 The antibiotic resistance pattern of the test bacterial isolates

\begin{tabular}{llll}
\hline $\begin{array}{l}\text { No of } \\
\text { antibiotics }\end{array}$ & Isolates & Source & Resistance pattern \\
\hline 4 & EC & Urine & Caz, Crx, Cxm, Ofl, Aug \\
5 & KG & Ear & Caz, Crx, Cxm, Ofl, Aug \\
6 & KG & Urine & Caz, Crx, Gen, Cxm, Ofl, Aug \\
& SA & Eye & Caz, Crx, Gen, Ctr, Cxc, Aug \\
& SA & Pus & Caz, Crx, Cxm, Cxc, Ofl, Aug \\
7 & KG & Wound Crx, Gen, Cxm, Ofl, Aug, Nit, \\
& & & Cpr \\
& EC & Wound Caz, Crx, Cxm, Ofl, Aug, Nit, & Cpr
\end{tabular}

Antibiotics abbreviations are as defined under "Materials and methods"

EC E. coli, KG Klebsiella granulomatis, SA S. aureus

Owing to the combination of excellent mechanical properties, biocompatibility, and slow biodegradability, spider silk has found tremendous applications in biomedical field, such as tissue engineering (Vendrely and Scheibel
2007). As additives in cosmetic products, such as shampoos, soaps, creams, and nail varnish, they enhance the brightness, softness, and/or toughness of the products (Vendrely and Scheibel 2007). Furthermore, spider-silk fibers could be applied in technical textiles (used for example in parachutes and bullet-proof vests) which demand high toughness in combination with sleaziness (Vendrely and Scheibel 2007). The production of spider silk in bacteria has been achieved through genetic engineering. The silks so formed were capable of self-assemblage to form nanofibrils which can be decorated with inorganic materials such as metals to produce nanowires. Therefore, the present study adds to the growing exploitation and utilization of spider cobweb as novel biomaterial with nanotechnological applications.

\section{Biosynthesis and characterization of AgNPs}

The hydrolyzed extract of cobweb mediated the synthesis of AgNPs within a period of 5 min under ambient 
Fig. 8 The synergistic activities of synthesized AgNPs with antibiotics on some clinical bacterial isolates
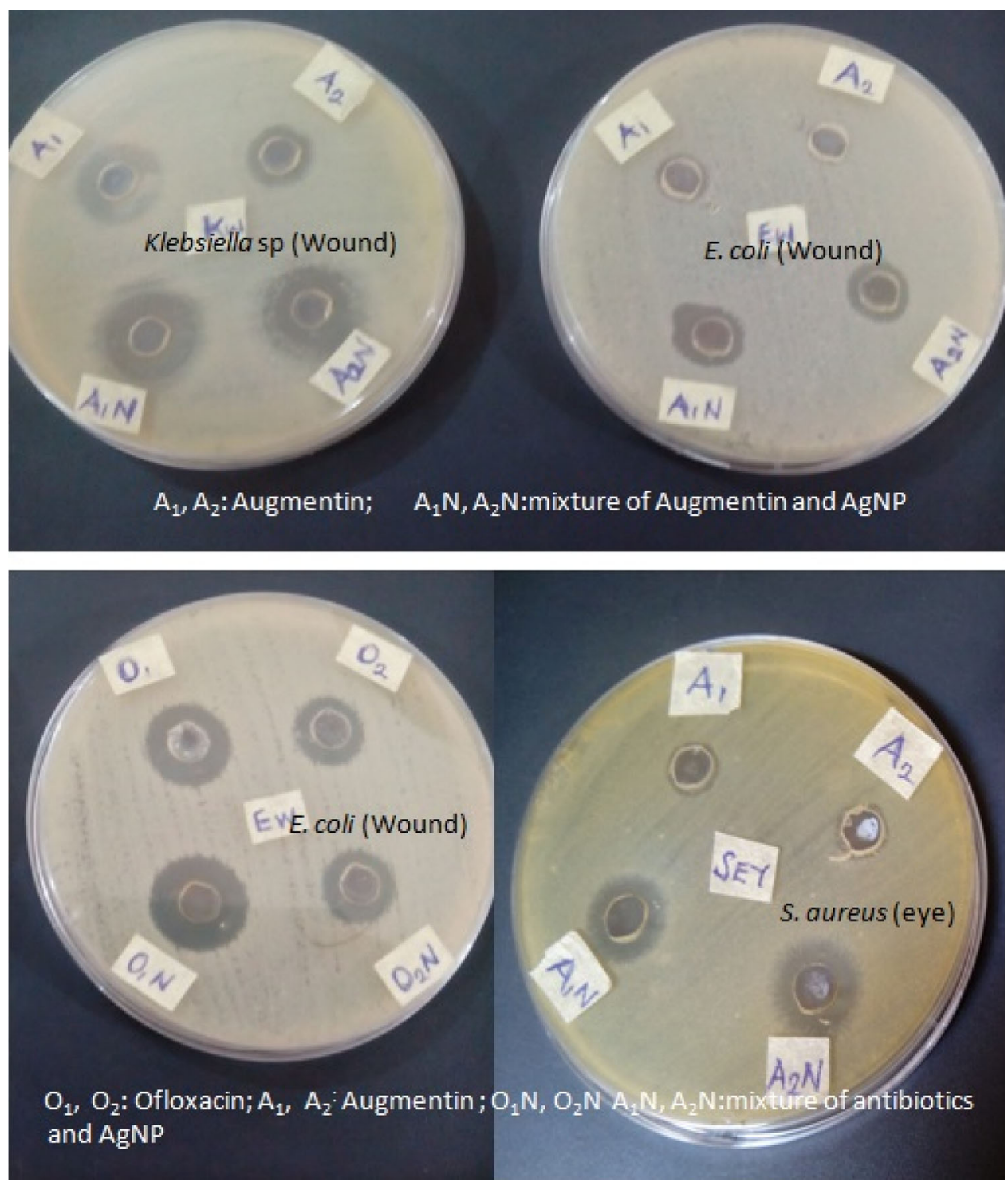

Table 2 The synergistic effect of biosynthesized AgNPs on the antibacterial activities of ofloxacin

\begin{tabular}{|c|c|c|c|c|c|}
\hline \multirow[t]{2}{*}{ Isolate } & \multirow[t]{2}{*}{ Source } & \multicolumn{4}{|c|}{ Zone of inhibition $(\mathrm{mm})$} \\
\hline & & $\mathrm{O}_{1}$ & $\mathrm{O}_{1}+\mathrm{AgNPs}$ & $\mathrm{O}_{2}$ & $\mathrm{O}_{2}+\mathrm{AgNPs}$ \\
\hline $\mathrm{EC}$ & Wound & $39 \pm 1.2$ & $41 \pm 3.0(5.1)$ & $38 \pm 2.1$ & $40 \pm 2.0(5.3)$ \\
\hline $\mathrm{EC}$ & Urine & $15 \pm 1.0$ & $18 \pm 2.4(20)$ & $13 \pm 0.5$ & $14 \pm 0.6(7.7)$ \\
\hline KG & Ear & $35 \pm 1.5$ & $38 \pm 0.5(8.6)$ & $37 \pm 1.2$ & $40 \pm 1.8(8.1)$ \\
\hline KG & Urine & $29 \pm 2.0$ & $34 \pm 0.8(17.24)$ & $29 \pm 0.8$ & $33 \pm 2.3(13.80)$ \\
\hline KG & Wound & $32 \pm 2.1$ & $35 \pm 1.0(9.4)$ & $30 \pm 1.6$ & $30 \pm 1.1(0.0)$ \\
\hline PA & Wound & $33 \pm 1.8$ & $35 \pm 2.2(6.1)$ & $30 \pm 1.5$ & $30 \pm 1.7(0.0)$ \\
\hline SA & Pus & $32 \pm 2.2$ & $34 \pm 1.1(6.3)$ & $32 \pm 1.4$ & $33 \pm 1.4(3.1)$ \\
\hline
\end{tabular}

Values in parentheses are \% improvement

All values are average of three readings

EC E. coli, KG K. granulomatis, PA P. aeruginosa, SA S. aureus, $O_{1}$ ofloxacin at $1 \mathrm{mg} / \mathrm{ml}, O_{2}$ ofloxacin at $500 \mu \mathrm{g} / \mathrm{ml}$ 
conditions of room temperature $\left(30 \pm 2{ }^{\circ} \mathrm{C}\right)$ with the characteristic dark-brown color (Fig. 1) which intensified with time but stabilized within $10 \mathrm{~min}$. Several authors have reported variation in the color of AgNP colloidal solutions due to the composition of biomolecules responsible for the synthesis of the nanoparticles. Recently, we reported the formation of dark-brown AgNP solution using the crude extracellular keratinase of Bacillus safensis LAU 13 (Lateef et al. 2015a).

The biosynthesized AgNPs displayed maximum absorbance at the wavelength of $436 \mathrm{~nm}$ (Fig. 2), which falls within the reported range of $391-440 \mathrm{~nm}$ for AgNPs (Thirumurugan et al. 2011; Zaki et al. 2011; Kannan et al. 2013; Priyadarshini et al. 2013; Lateef et al. 2015a). It was observed that dilution ratio of 1:40 (extract: $\mathrm{AgNO}_{3}$ solution), and $\mathrm{pH} 8.5$ produced highest yield of AgNPs with maxima absorbance readings at $436 \mathrm{~nm}$ (Figs. 3, 4). The particles were of good stability on storage giving rise to clear solution when dispersed in distilled water. The FTIR absorption spectrum (Fig. 5) showed distinct peaks at $3298,2359,2089$, and $1635 \mathrm{~cm}^{-1}$, indicating that proteins were the capping and stabilization molecules in the synthesis of AgNPs. The bands 3298 and 1635 are typical of $\mathrm{N}-\mathrm{H}$ bond of amines, and $\mathrm{C}=\mathrm{C}$ stretch of alkenes or $\mathrm{C}=\mathrm{O}$ stretch of amides, respectively (Shankar et al. 2014). It can therefore be concluded that protein hydrolysates obtained from the protein-rich spider cobweb (Roozbahani et al. 2014) were responsible for the capping and stabilization of the AgNPs. It can be inferred that the carboxylate groups obtained from alkaline degradation of cobweb would be a reducing agent for the generation of AgNPs, while $\mathrm{COO}^{-}$ and $\mathrm{NH}_{2}{ }^{+}$groups stabilized the AgNPs and prevented their precipitation.

Microscopic analysis using TEM showed that the biosynthesized AgNPs were spherical in shape with sizes ranging 3-50 nm (Fig. 6a), and this conforms with similar
Fig. 9 Antibacterial activities of synthesized AgNPs on bacteria inoculated into emulsion paint
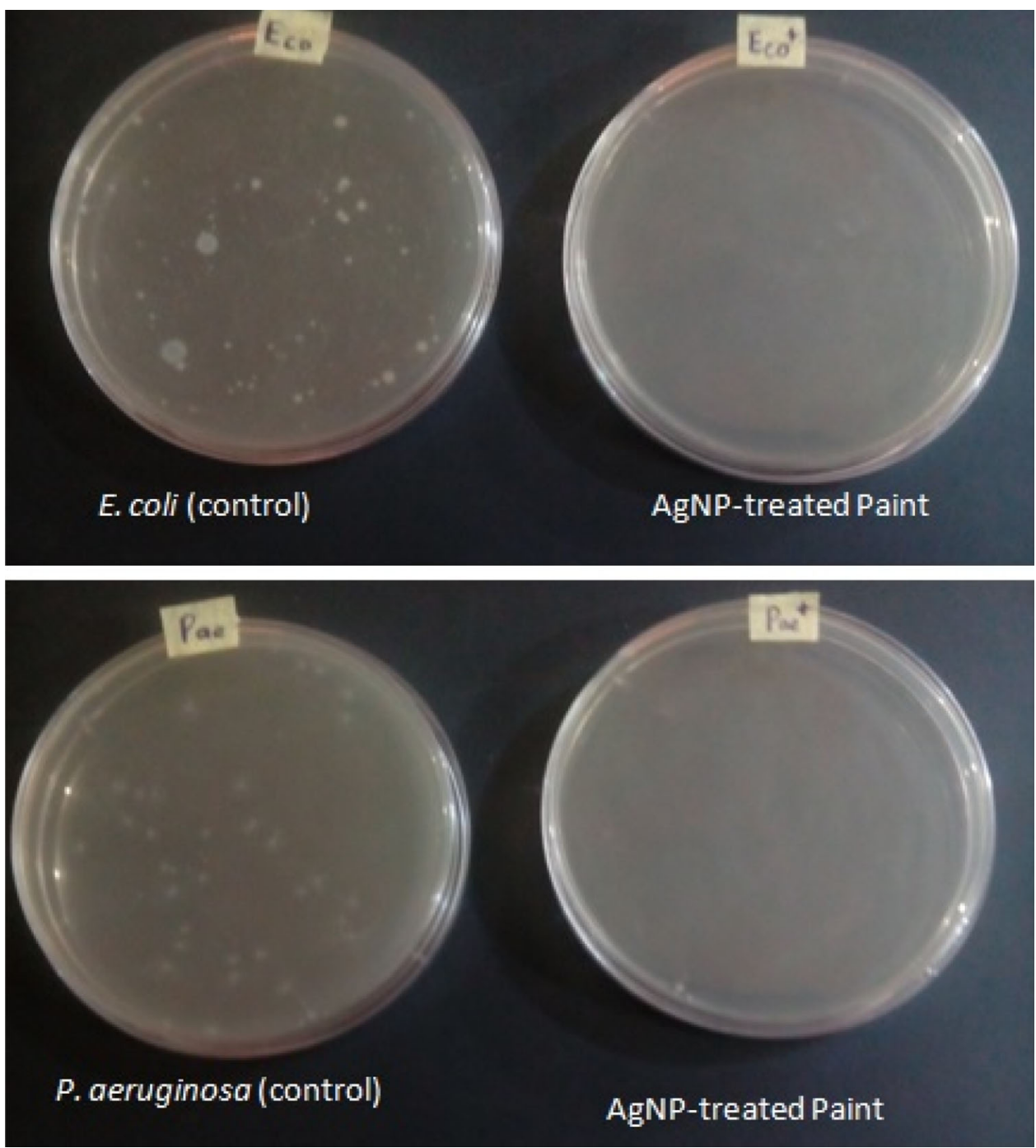
Fig. 10 Antifungal activities of synthesized AgNPs on fungi inoculated into emulsion paint
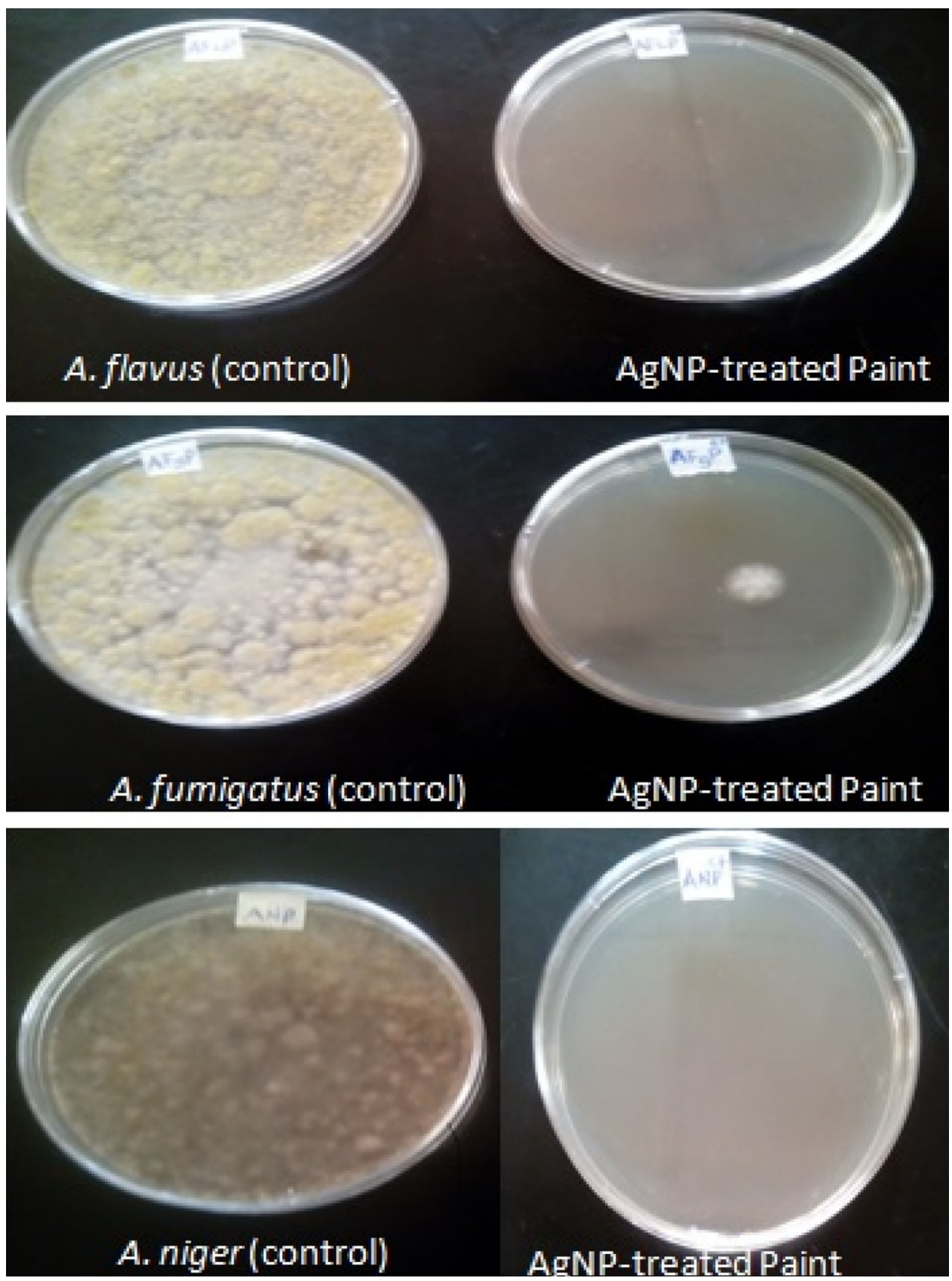

results earlier reported by several authors (Zaki et al. 2011; Kannan et al. 2013; Lateef et al. 2015a). The particles were well dispersed, an indication of good stability to avoid aggregation. The EDX pattern (Fig. 6b) showed the predominant presence of silver in the AgNP solution (Shameli et al. 2011; Salem et al. 2014) with the characteristic ring-like SAED pattern (Fig. 6c) typical of the face-centered cubic crystalline structure of silver (Shankar et al. 2014). These evidences showed that spider cobweb is a novel biomaterial for the green and eco-friendly synthesis of AgNPs which is a biofunctional application of the fibers.

\section{Antimicrobial activities of biosynthesized AgNPs}

The biosynthesized AgNPs displayed considerable inhibitory activities against some clinical isolates of bacteria (Fig. 7). It is noteworthy that though the bacterial isolates were multi-drug resistant strains showing resistance to 4-7 antibiotics (Table 1), the AgNPs at concentrations of 80 and $100 \mu \mathrm{g} / \mathrm{ml}$ effectively inhibited strains of $E$. coli, $S$. aureus, and Klebsiella granulomatis. In our several studies, we have documented high level of antibiotic resistance among bacterial isolates obtained from diverse sources in Nigeria (Adewoye and Lateef 2004; Lateef 2004; Lateef

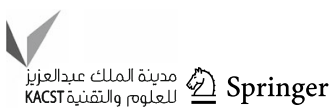


Table 3 The synergistic effect of biosynthesized AgNPs on the antibacterial activities of augmentin

\begin{tabular}{|c|c|c|c|c|c|}
\hline \multirow[t]{2}{*}{ Isolate } & \multirow[t]{2}{*}{ Source } & \multicolumn{4}{|c|}{ Zone of inhibition $(\mathrm{mm})$} \\
\hline & & $\mathrm{A}_{1}$ & $\mathrm{~A}_{1}+\mathrm{AgNPs}$ & $\mathrm{A}_{2}$ & $\mathrm{~A}_{2}+\mathrm{AgNPs}$ \\
\hline $\mathrm{EC}$ & Wound & $9 \pm 0.4$ & $12 \pm 0.2(33.3)$ & $0 \pm 0.0$ & $12 \pm 0.4(100)^{*}$ \\
\hline $\mathrm{EC}$ & Urine & $17 \pm 1.1$ & $20 \pm 0.4(17.7)$ & $15 \pm 0.1$ & $17 \pm 0.4(13.3)$ \\
\hline KG & Urine & $12 \pm 0.6$ & $13 \pm 0.4(8.3)$ & $0 \pm 0.0$ & $11 \pm 0.5(100)^{*}$ \\
\hline KG & Wound & $16 \pm 0.8$ & $17 \pm 1.0(6.3)$ & $12 \pm 0.2$ & $18 \pm 1.2(50.0)$ \\
\hline PA & Wound & $25 \pm 0.5$ & $27 \pm 1.4(8.0)$ & $15 \pm 0.2$ & $16 \pm 0.6(6.7)$ \\
\hline SA & Pus & $23 \pm 1.2$ & $26 \pm 1.0(13.0)$ & $21 \pm 1.1$ & $25 \pm 1.2(19.1)$ \\
\hline
\end{tabular}

Values in parentheses are $\%$ improvement

All values are average of three readings

EC E. coli, KG K. granulomatis, PA P. aeruginosa, SA S. aureus, $A_{1}$ augmentin at $1 \mathrm{mg} / \mathrm{ml}, A_{2}$ augmentin at $500 \mu \mathrm{g} / \mathrm{ml}$

* \% improvement truncated to 100

Table 4 The synergistic effect of biosynthesized AgNPs on the antibacterial activities of cefixime

\begin{tabular}{|c|c|c|c|c|c|}
\hline \multirow[t]{2}{*}{ Isolate } & \multirow[t]{2}{*}{ Source } & \multicolumn{4}{|c|}{ Zone of inhibition (mm) } \\
\hline & & $\mathrm{C}_{1}$ & $\mathrm{C}_{1}+\mathrm{AgNPs}$ & $\mathrm{C}_{2}$ & $\mathrm{C}_{2}+\mathrm{AgNPs}$ \\
\hline $\mathrm{EC}$ & Wound & $11 \pm 0.2$ & $11 \pm 1.2(0.0)$ & $7 \pm 0.4$ & $11 \pm 1.0(57.1)$ \\
\hline $\mathrm{EC}$ & Urine & $29 \pm 1.3$ & $31 \pm 1.4(6.9)$ & $30 \pm 0.2$ & $32 \pm 2.1(6.7)$ \\
\hline KG & Urine & $7 \pm 0.4$ & $14 \pm 0.2(100)$ & $7 \pm 0.4$ & $13 \pm 0.2(85.7)$ \\
\hline KG & Wound & $24 \pm 0.8$ & $24 \pm 0.6(0.0)$ & $23 \pm 1.2$ & $23 \pm 1.0(0.0)$ \\
\hline PA & Wound & $26 \pm 0.2$ & $27 \pm 1.8(3.9)$ & $26 \pm 0.4$ & $28 \pm 1.0(7.7)$ \\
\hline
\end{tabular}

Values in parentheses are \% improvement

All values are average of three readings

EC E. coli, KG K. granulomatis, PA P. aeruginosa, SA S. aureus, $C_{1}$ cefixime at $1 \mathrm{mg} / \mathrm{ml}, C_{2}$ cefixime at $500 \mu \mathrm{g} / \mathrm{ml}$

et al. 2004, 2005, 2006, 2007, 2010; Lateef and Ojo 2015). The antibacterial activities of AgNPs as obtained in this study have been reported in previous studies (Priyadarshini et al. 2013; Kanmani and Lim 2013; Salem et al. 2014; Shankar et al. 2014; Lateef et al. 2015a). The antibacterial activities of AgNPs have been attributed to the interaction of AgNPs with sulphur and phosphorus containing biomolecules in the bacterial cell. As the particles enter into the cell, cell-killing is initiated through the attack of the respiratory chain and cell division (Mahendra et al. 2009).

The study has further shown that AgNPs can be applied synergistically to potentiate the antimicrobial activities of some antibiotics. At antibiotic concentrations of $1 \mathrm{mg} / \mathrm{ml}$ and $500 \mu \mathrm{g} / \mathrm{ml}$, the inclusion of AgNPs at concentration of $100 \mu \mathrm{g} / \mathrm{ml}$ improved the antibacterial activities of augmentin, ofloxacin and cefixime against some multi-drug resistant strains of bacteria (Fig. 8; Table 1). Improved activities in the ranges of 6.3-100, 3.1-20 and 3.9-100\% were obtained for augmentin, ofloxacin and cefixime, respectively (Tables 2, 3,4). Therefore, it can be concluded that the biosynthesized AgNPs can find applications as antibacterial agent against multi-drug resistant bacteria either singly or in combination with antibiotics. Studies have demonstrated synergistic antibacterial effects of AgNPs on some antibiotics against Gram-positive and Gram-negative bacteria (Fayaz et al. 2010; Devi and Joshi 2012). Through the disruption of cell wall by some antibiotics, the AgNPs can be easily internalized by the bacterial cell thereby enhancing toxicity to the cell.

The practical application of the biosynthesized AgNPs at the concentration of $5 \mu \mathrm{g} / \mathrm{ml}$ as an additive in emulsion paint was demonstrated in this work. The results showed total obliteration of E. coli and P. aeruginosa (Fig. 9), and A. niger and A. flavus (Fig. 10) in AgNP-treated paint as against the control. In the case of $A$. fumigatus, remarkable antifungal activity was also demonstrated leading to the appearance of a single colony after $48 \mathrm{~h}$ of incubation as against the profuse growth obtained on the control plate (Fig. 10). The application of nanoparticles as additives in paints have been previously reported (Mueller and Nowack 2008; Rajarathinam et al. 2014), and it has been alluded that paint industry may benefit from the use of novel 
nanomaterials including nanosilver to improve the quality of the paint against microbial attack, biodegradation and chemical deterioration (Kaiser et al. 2013). These considerable antimicrobial activities of cobweb extract-mediated AgNPs have shown that the nanomaterials can find useful applications in biomedical fields and built environment. This has shown the novelty of spider cobweb as an important biomaterial for the rapid green and eco-friendly synthesis of AgNPs.

\section{Conclusion}

This study has led to the green synthesis of AgNPs using the extract of spider cobweb under ambient condition. The polydispersed particles were spherical in shape with size range of 3-50 nm. The particles were crystalline in nature, showing the characteristic face-centered cubic structure. The particles displayed good antibacterial activities against multi-drug resistant strains of bacteria in both single and synergistic studies. The antimicrobial potency of the biosynthesized AgNPs was demonstrated in paint, leading to the total elimination of E. coli, $P$. aeruginosa, A. niger and A. flavus when the particles were used as additive. Therefore, this work has established the relevance of spider cobweb in nanobiotechnology, through the green and ecofriendly synthesis of AgNPs with potent antimicrobial activities. This study has expanded the frontiers in the use of novel biomaterials for the green synthesis of nanoparticles. To the best of our knowledge, this report represents the first reference to spider cobweb and any metabolite thereof from arthropods for the green synthesis of nanoparticles.

Open Access This article is distributed under the terms of the Creative Commons Attribution 4.0 International License (http:// creativecommons.org/licenses/by/4.0/), which permits unrestricted use, distribution, and reproduction in any medium, provided you give appropriate credit to the original author(s) and the source, provide a link to the Creative Commons license, and indicate if changes were made.

\section{References}

Adewoye SO, Lateef A (2004) Assessment of the microbiological quality of Clarias gariepinus exposed to an industrial effluent in Nigeria. Environmentalist 24:249-254

Andrade E, Villanova F, Borra P, Leite K, Troncone L, Cortez I, Messina L, Paranhos M, Claro J, Srougi M (2008) Penile erection induced in vivo by a purified toxin from the Brazilian spider Phoneutria nigriventer. Br J Urol Int 102(7):835-837

Andrews JM (2005) BSAC standardized disc susceptibility testing method (version 4). J Antimicrob Chemother 56:60-76

Augustine R, Kalarikkal N, Thomas S (2014) A facile and rapid method for the black pepper leaf mediated green synthesis of silver nanoparticles and the antimicrobial study. Appl Nanosci 4:809-818

Ayedun H, Adewole A, Osinfade BG, Ogunlusi RO, Umar BF, Rabiu SA (2013) The use of spider webs for environmental determination of suspended trace metals in industrial and residential areas. J Environ Chem Ecotoxicol 5(2):21-25

Bhat R, Deshpande R, Ganachari SV, Huh DO, Venkataraman A (2011) Photo-irradiated bio-synthesis of silver nanoparticles using edible mushroom Pleurotus florida and their antibacterial activity studies. Bioinorg Chem Appl 2011:1-7

Blackledge TA, Kuntner M, Agnarsson I (2011) The form and function of spider orb webs: evolution from silk to ecosystems. Adv Insect Physiol 41:175-262

Chakraborty DS (2009) Antibacterial activities of cobweb protein. European Congress of Clinical Microbiology and Infectious Diseases

Chortyk TO, Severson RF, Cutler HC, Siesson VA (1993) Antibiotic activities of sugar esters isolated from selected Nicotiana species. Biosci Biotechnol Biochem 57:1355-1356

Cutler B (1980) Arthropod cuticle features and arthropod monophyly. Experientia 36(8):953

Denver Museum of Nature and Science (2015) Spider biology. http:// www.dmns.org/colorado-spider-survey/spider-biology/. Accessed on 1 Mar 2015

Devi LS, Joshi SR (2012) Antimicrobial and synergistic effects of silver nanoparticles synthesized using: soil fungi of high altitudes of Eastern Himalaya. Mycobiol 40:27-34

El-Batal AI, ElKenawya NM, Yassin AS, Amin MA (2015) Laccase production by Pleurotus ostreatus and its application in synthesis of gold nanoparticles. Biotechnol Rep 5:31-39

Fayaz AM, Balaji K, Girilal M, Yadav R, Kalaichelvam PT, Venketesan R (2010) Biogenic synthesis of silver nanoparticles and their synergistic effect with antibiotics: a study against gram-positive and gram-negative bacteria. Nanomed Nanotechnol Biol Med 6:103-109

Glime JM (2013) Arthropods: arachnida—spider biology. Chap 7-2 In: Glime JM (ed) Bryophyte Ecology. Volume 2. Bryological 7-2-1 Interaction. Ebook sponsored by Michigan Technological University and the International Association of Bryologists

Gomes SC, Leonor IB, Mano JF, Reis RL, Kaplan DL (2010) Functionalized silk biomaterials for bone regeneration. Semana de Engenharia. Guimarães, 11 a 15 de Outubro, pp 1-2

Heimer S (1988) Wunderbare Welt der Spinnen, Urania

Hose GC, James JM, Gray MR (2002) Spider webs as environmental indicators. Environ Pollut 120(3):725-733

Insect Identification (2015). http://www.insectidentification.org/ spiders.asp. Accessed on 1 Mar 2015

Kaiser JP, Zuin S, Wick P (2013) Is nanotechnology revolutionizing the paint and lacquer industry? A critical opinion. Sci Total Environ 442:282-289

Kanmani P, Lim ST (2013) Synthesis and structural characterization of silver nanoparticles using bacterial exopolysaccharide and its antimicrobial activity against food and multidrug resistant pathogens. Process Biochem 48:1099-1106

Kannan RRR, Arumugam R, Ramya D, Manivannan K, Anantharaman P (2013) Green synthesis of silver nanoparticles using marine macroalga Chaetomorpha linum. Appl Nanosci 3:229-233

Lateef A (2004) The microbiology of a pharmaceutical effluent and its public health implications. World J Microbiol Biotechnol 20:167-171

Lateef A, Ojo MO (2015) Public health issues in the processing of cassava (Manihot esculenta) for the production of 'lafun' and the application of hazard analysis control measures. Qual Assur Saf Crops Foods. doi:10.3920/QAS2014.0476

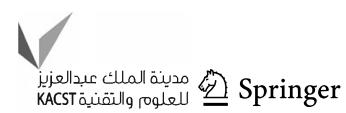


Lateef A, Oloke JK, Gueguim-Kana EB (2004) Antimicrobial resistance of bacterial strains isolated from orange juice products. Afr J Biotechnol 3:334-338

Lateef A, Oloke JK, Gueguim-Kana EB (2005) The prevalence of bacterial resistance in clinical, food, water and some environmental samples in Southwest Nigeria. Environ Monit Assess 100:59-69

Lateef A, Oloke JK, Gueguim-Kana EB, Pacheco E (2006) The microbiological quality of ice used to cool drinks and foods in Ogbomoso metropolis, southwest, Nigeria. Internet J Food Saf 8:39-43

Lateef A, Yekeen TA, Ufuoma PE (2007) Bacteriology and genotoxicity of some Pharmaceutical wastewaters in Nigeria. Int J Environ Health 1(4):551-562

Lateef A, Davies TE, Adelekan A, Adelere IA, Adedeji AA, Fadahunsi AH (2010) Akara Ogbomoso: microbiological examination and identification of hazards and critical control points. Food Sci Technol Int 16:389-400

Lateef A, Adelere IA, Gueguim-Kana EB, Asafa TB, Beukes LS (2015a) Green synthesis of silver nanoparticles using keratinase obtained from a strain of Bacillus safensis LAU 13. Int Nano Lett 5:29-35

Lateef A, Adelere IA, Gueguim-Kana EB (2015b) The biology and potential biotechnological applications of Bacillus safensis. Biologia 70(4):411-419

Lewis RJ, Garcia ML (2003) Therapeutic potential of venom peptides. Nature Rev Drug Discov 2(10):790-802

Mahendra R, Alka Y, Aniket G (2009) Silver nanoparticles as a new generation of antimicrobials. Biotechnol Adv 27(1):76-83

Maloney D, Drummond FA, Alford R (2003) Spider predation in agroecosystems: can spiders effectively control pest populations. Technical Bulletin 190.1-32. ISSN 1070.1524. Maine Agricultural and Forest Experiment Station, The University of Maine

Mishra A, Kumari M, Pandey S, Chaudhry V, Gupta KC, Nautiyal CS (2014) Biocatalytic and antimicrobial activities of gold nanoparticles synthesized by Trichoderma sp. Bioresour Technol 166:235-242

Mueller NC, Nowack B (2008) Exposure modeling of engineered nanoparticles in the environment. Environ Sci Technol 42:4447-4453

Nazeruddin GM, Prasad NR, Prasad SR, Shaikh YI, Waghmare SR, Adhyapak P (2014) Coriandrum sativum seed extract assisted in situ green synthesis of silver nanoparticle and its antimicrobial activity. Ind Crops Prod 60:212-216

Novak K (2001) Spider venom helps hearts keep their rhythm. Nature med 7(2): 155

Ødegaard F (2000) How many species of arthropods? Erwin's estimate revised. Biol J Linnean Soc 71(4):583-597

Priyadarshini S, Gopinath V, Priyadharsshini NM, Ali DM, Velusamy P (2013) Synthesis of anisotropic silver nanoparticles using novel strain, Bacillus flexus and its application. Coll Surf B Biointerface 102:232-237
Rajarathinam M, Dhanapal D, Morukattu G, Joseph S, Thangavelu KP (2014) Imparting potential antibacterial and antifungal activities to water based interior paint using nanoparticles of silver as an additive-an ecofriendly approach. Adv Sci Eng Med 6(6):676-682

Rajeshkumar S, Ponnanikajamideen M, Malarkodi C, Malini M, Annadurai G (2014) Microbe-mediated synthesis of antimicrobial semiconductor nanoparticles by marine bacteria. J Nanostruct Chem 4:96-102

Raliya R, Tarafdar JC (2014) Biosynthesis and characterization of zinc, magnesium and titanium nanoparticles: an eco-friendly approach. Int Nano Lett 4(1):1-10

Roozbahani H, Asmar M, Ghaemi N, Issazadeh K (2014) Evaluation of antimicrobial activity of spider silk Pholcus phalangioides against two bacterial pathogens in food borne. Int $\mathrm{J}$ Adv Biol Biomed Res 2(7):2197-2199

Ruppert EE, Fox RS, Barnes RD (2004) Invertebrate zoology ,7th ed, Brooks/Cole. ISBN:0-03-025982-7

Salem WM, Haridy M, Sayed WF, Hassan NH (2014) Antibacterial activity of silver nanoparticles synthesized from latex and leaf extract of Ficus sycomorus. Ind Crops Prod 62:228-234

Shameli K, Ahmad MB, Zargar M, Wan Yunus WMZ, Ibrahim NA, Sha-banzadeh P, Ghaffari-Moghadam M (2011) Synthesis and characterization of silver/montmorillonite/chitosan bionanocomposites by chemical reduction method and their antibacterial activity. Int J Nanomed 6:271-284

Shankar S, Jaiswal L, Aparna RSL, Prasad RGSV (2014) Synthesis, characterization, in vitro biocompatibility, and antimicrobial activity of gold, silver and gold silver alloy nanoparticles prepared from Lansium domesticum fruit peel extract. Mat Lett 137:75-78

Shanmugam N, Rajkamal P, Cholan S, Kannadasan N, Sathishkumar K, Viruthagiri G, Sundaramanickam A (2014) Biosynthesis of silver nanoparticles from the marine seaweed Sargassum wightii and their antibacterial activity against some human pathogens. Appl Nanosci 4:881-888

Shivaji S, Madhu S, Singh S (2011) Extracellular synthesis of antibacterial silver nanoparticles using psychrophilic bacteria. Process Biochem 46(9):1800-1807

Thirumurugan A, Tomy NA, Kumar HP, Prakash P (2011) Biological synthesis of silver nanoparticles by Lantana camara leaf extracts. Int J Nanomat Biostruct 1(2):22-24

Tszydel M, Sztajnowski S, Michalak M, Wrzosek H, Kowalska S, Krucińska I, Lipp-Symonowicz B (2009) Structure and physical and chemical properties of fibres from the fifth larval instar of caddis-flies of the species Hydropsyche angustipennis. Fibres Text Eastern Eur 17:7-12

Vendrely C, Scheibel T (2007) Biotechnological production of spidersilk proteins enables new applications. Macromol Biosci 7(4):401-409

Zaki S, El-Kady MF, Abd-El-Haleem D (2011) Biosynthesis and structural characterization of silver nanoparticles from bacterial isolates. Mater Res Bull 46:1571-1576 